\title{
KELET-KÖZÉP-EURÓPA ÉS MAGYARORSZÁG AGRÁRGAZDASÁGA AZ EURÓPAI UNIÓHOZ VALÓ CSATLAKOZÁS ELŐTT ${ }^{1}$
}

\author{
(The Agriculture of Central Europe and Hungary Before the \\ Accession to the European Union)
}

\section{BUDAY-SÁNTHA ATTILA}

Az Európai Unióhoz való csatlakozás idejének közeledtével az EU-n belül - föleg Ausztriában - egyre inkább felerősödnek azok a hangok, amelyek a csatlakozás idejének későbbi idöpontra halasztását, és a mezögazdaságnak nyújtott támogatások (kompenzációk) - a belépök számára hátrányos módon - egyenlötlen elosztását szorgalmazzák. A tanulmány arra kiván rámutatni, hogy a belépök esetében nem egy homogén agrártérségröl van szó, hanem eltérỏ adottságú országokról. A felmerülö problémákat országonként kell vizsgálni és kezelni. A gazdaság fejlödése, az életszínvonal növelése nemcsak a veszélyesnek tartott munkaerömozgást fékezné, de a növekvő belsö fogyasztás az élelmiszer feleslegek kialakulását is megakadályozná.

\section{Eltúlzott veszélyek}

Hosszú előkészitő idöszak után ebben az évben megkezdődtek a csatlakozási tárgyalások négy kelet-közép-európai (Lengyelország, Csehország, Magyarország, Szlovénia) és egy balti térségben elhelyezkedỏ országgal (Észtország). Ezzel egyidejüleg felerösödtek az EU-n belül azok a tiltakozások és félelmek, amelyek ezen országok csatlakozásának várható negatív következményeit hangsúlyozzák.

Ezek közül a legfontosabbak a következök:

- A belépő országok gazdasági elmaradottsága következtében ezeknek az országoknak a felzárkóztatási igénye elvonja a fejlesztési forrásokat az eddig ebben részesüló EU-n belưli területektöl.

- A munkajövedelmek nagymértékủ eltérése olyan volumenú munkaerỏmozgást indít el keletról nyugati irányba, melynek következményei a jelenlegi tagországokban alig lesznek kezelhetöek.

- A csatlakozó országok nagy agrárpotenciálja egy kínálati többletet fog eredményezni, mely az EU túltermelési válságát tovább mélyíti.

A közép-európai országok csatlakozási folyamatát hosszú távú politikai érdekek határozzák meg, így a felmerülő kérdésekre adandó válaszok is attól fưggően kerülnek megfogalmazásra. Elöljáróban azonban ki kell hangsúlyoznunk, hogy az EU és a NATO bővítése a kölcsönös szuikségszerúség, az előnyök és a hátrányok, a várható költségek és a haszon egyưttes mérlegelése alapján valósul meg. Európa két integráló politikai és gazdasági tényezője Oroszország és az Európai Unió. A szovjet birodalom szétesésével a két nagy rendszer közötti kis államok politikai és gaz- 
dasági vákuumba kerü'ıek, amit az EU-val kötött társulási egyezmények enyhítettek, de nem szüntettek meg. A régió politikai és gazdasági bizonytalansága mindig destabilizáló hatású lesz Európa egészére nézve, részben a belülröl feszitő gazdasági gondok miatt, részben pedig azért, mert a nagyhatalmi ambíciók viszonylag kis kockázattal járó játékterévé válhatnak. A politikai stabilizáció megteremtése tehát összeurópai érdek. Az élesedő globális gazdasági versenyben az európai belső piac bővítése a kontinens jövőbeli versenyképességének az alapvető feltétele. KeletKözép-Európa és Kelet-Európa gazdasági jelentőségét az EU számára jól bizonyitja az a tény, hogy 1997-ben az EU export többletének 83\%-át az ebbe a térségbe irányuló kereskedelemben érte el. Nem is szólva arról a jelentős mezőgazdasági termék és élelmiszer exportról, amely a kilencvenes években az EU fölös készleteit vezette le, sokszor azon az áron, hogy tovább növelte a gazdasági átmenetben lévő országok gazdasági válságát. Így ebben a térségben a gazdasági fejlődés felgyorsítása egyben az EU gazdasági fejlődésének is egy fontos kritériuma. Más oldalról viszont igaz az, hogy a közép- és kelet-európai államoknak az EU politikai és gazdasági rendszeréhez való integrálódása nélkül egyszerüen nincs lehetőségük egy tartós gazdasági fejlödésre, és a fejlett államokhoz való felzárkózásra.

A népességnek a fejlett államok felé irányuló, tehát nyugati irányú mozgása világtendencia. Ez a fejlődési szakadék növekedése következtében még világszinten megoldhatatlan gondot jelent, de Európában éppen a társult országok fejlődésének a felgyorsításával lehetne azt minimálisra csökkenteni. Az emberek többsége ragaszkodik a szülöhelyéhez és csak szélsőséges esetekben hajlandó azt elhagyni.

A csatlakozás ellenzőinek az egyik döntő érve a várható agrár túltermelés kérdése. Ezzel kapcsolatban három megjegyzést szeretnék elöljáróban tenni.

1) A földrajzi közelség és szorosabb együttmüködés miatt az osztrákok és a németek érthetik meg igazán, hogy bár a csatlakozó országok körét földrajzilag és politikailag egységes térségként kezelik, itt teljesen más természeti adottságú, termelési szerkezetủ országokról van szó.

2) A társult tíz ország agrártermelésében - a jelentős termeléscsökkenés ellenére - bekövetkező időszakos túltermelés az életszinvonal drasztikus visszaesésének a következménye, amelynek javulása esetén a jelenlegi élelmiszer feleslegek jelentös része rögtön eltünne.

3) Az EU és a tíz ország között kötött társulási egyezménynek egyértelmủ nyertcse az Európai Unió. Egyedül Magyarország tudta megőrizni jelentős mértékben a mezőgazdasági exporttöbbletét, bár ott is az export és import aránya az 1989 évi 6:1-röl 3:1-re csökkent. Kis mértékủ exporttöbbletet tud még felmutatni Bulgária. A többi ország nettó élelmiszerimportőr.

A csatlakozásra kijelölt öt volt szocialista ország közül a legnagyobb bizonytalansággal a lengyel mezögazdaság helyzete ítélhetỏ meg, mert az a szétaprózott birtokszerkezet, a tókehiány és a mezőgazdasági túlnépesedés (népesség 27\%-a a mezőgazdaságból él) miatt mindig a lehetőségeinek határa alatt teljesített. Jelentősebb fejlesztés esetén elsősorban tej- és tejtermék, marhahús, sertéshús, cukor, burgonya és bizonyos zöldség- és gyümölcsfélék (pl. alma, bogyósok stb.) esetében lehetne jelentős exportőr. Csehország a mezőgazdasági termelés számára kedvezőtlen adott- 
Kelet-Közép-Európa és Magyarország agrárgazdasága az Európai Unióhoz való csatlakozás elött Tér és Társadalom 12. évf. 1998/4. 21-27. p.

TÉT XII. évf. 1998 - 4

Kelet-Közép-Európa és Magyarország... 23

ságai miatt, magas fogyasztási szint mellett élelmiszer importra szorul. Jelentösebb exportra elsösorban tej- és tejtermék, marhahús, cukor, sörárpa és komló esetében nyílik lehetósége. A szlovén mezögazdaság sem képes fedezni a belső fogyasztást, exportra elsősorban tej és tejtermékek, bor és baromfihús kerülhet. Magyarország agrárpotenciálja jelenleg 50-60\%-ban van csak kihasználva. A piactól függỏen búza, kukorica (ảllatlétszámtól fưgg), sertés- és baromfihús, valamint napraforgómag és olaj, bor, zöldség- és gyümölcs terén produkálhat jelentösebb volumenü exportot. A társult európai országok közül Szlovákia nagy mezőgazdasági többletekkel területi adottságai miatt sem rendelkezhet, többlete búzából, sertéshúsból, burgonyából képzódhet. Románia rendkiviül alacsony technológiai színvonala miatt kukoricából és napraforgómagból és -olajból, borból, valamint élőjuhból rendelkezhet felesleggel. Bulgária esetében a termelés a klasszikus kertészeti termékek, a szölö, a bor, a zöldség és a gyuumölcsfélék, valamint a dohány esetében haladja meg a belsỏ keresletet. Az egyetlen balti állam, az eddig nem említett Észtország tej- és tejtermék felesleggel rendelkezik. Összefoglalóan az öt csatlakozni kívánó ország esetében piaci feszültséget a tej- és tejtermék, a marhahús és sertéshús, valamint az alma kínálatának növekedése okozhat, de ez is nagymértékben attól függ, hogy a belső fogyasztás hogyan alakul.

\section{A magyar agrárgazdaság a csatlakozás elött}

A magyar mezőgazdaság az 1989-ben kezdődő átszervezése óta tartós válságban van. Ennek okai részben külső, részben pedig belső tényezőkben kereshetök. A külsỏ okok közőtt elsőként a keleti piacok elvesztését kell megemlíteni, amelyet a zöldség- és konzerv-, a szölö-, bor-, valamint a sertéshús- és baromfihús-termelés azóta sem tudott kiheverni. A belső okok között is elsỏ helyre kell tenni az életszínvonal drasztikus csökkenését (a magyar népesség ma a hetvenes éveknek megfeleló életszínvonalon él), amely a fogyasztás $15-20 \%$-os visszaesésével járt (l. táblázat). Alapvetően ez az oka annak, hogy bármely, a termelés növelésére irányuló kísérlet kereslet hiányában piaci zavarokat okoz. A belső okok között kell megemlíteni a részben nyugati ösztönzésre végrehajtott privatizációt, amely a kb. 2,4 millió 3-4 ha-os tulajdonossal átláthatatlan földtulajdoni viszonyokat hozott létre és szinte alig átlátható agrárpiacot teremtett, ahol a rosszul felszerelt, gyakran képzetlen termelök nagy tömege jelent meg.

1. TÁBLÁZAT

Az egy före jutó éves fogyasztảs $(\mathrm{kg})$

(Yearly Consumption perPerson in Kilogrammes)

\begin{tabular}{|l|c|c|c|c|}
\hline Megnevezés & $1986-90$ & $1991-95$ & 1995 & 1997 \\
\hline Húsfélék & 77,2 & 68,5 & 63,1 & 60,0 \\
\hline Ebböl: sertéshús & 42,1 & 32,5 & 27,4 & 25,0 \\
\hline Tej- és tejtermék & 188,0 & 149,4 & 133,4 & 136,0 \\
\hline Tojás & 19,6 & 18,9 & 16,7 & 16,2 \\
\hline Gyümölcs & 74,5 & 69,7 & 58,3 & - \\
\hline
\end{tabular}

Forrás: A magyar mezőgazdaság és élelmiszeripar számokban. Budapest, FM. 1997. 13. o. 
A kialakult állapot sok tekintetben hasonlít az I. világháború utáni helyzethez, amikor a belsỏ és külsö piacvesztés és a modernizációt gátló tőkehiány együtt okozott gondokat. Tulajdonképpen ezzel, valamint a korábbi évtizedekben az ágazatnak a térség országai közül kiemelkedó színvonalával, kifejezett exportőr jellegével magyarázható, hogy a termelés visszaesése a régióban a legnagyobb volt (2. táblá$z a t)$.

\section{TÁBLÁZAT}

A mezögazdasági termelés volumenének alakulása (1988-1995)

(The Change in Agricultural Production Between 1988 and 1995)

\begin{tabular}{|l|c|}
\hline \multicolumn{1}{|c|}{ Ország } & $\%$-0s viszonyszám \\
\hline Szlovénia & 100,8 \\
\hline Lengyelország & 92,0 \\
\hline Cseh Köztársaság & 77,3 \\
\hline Bulgária & 76,7 \\
\hline Szlovák Köztársaság & 70,0 \\
\hline Magyarország & 63,2 \\
\hline Észtország & 56,5 \\
\hline Litvánia & 46,4 \\
\hline Lettország & 45,5 \\
\hline
\end{tabular}

Forrás: OECD; Benet Iván: Rendszerváltás és agrárgazdaság. Magyar agrárgazdaság jelene és kilátásai. Budapest, Magyar Tudományos Akadémia 1997. 172. 0 .

A nagyobb gond, hogy a kialakult stagnáló állapotból a mezőgazdaság nem tudott kikerülni. Az utóbbi négy évben ugyan a növénytermesztés hozamai a csapadékosabb idōjárás hatására növekedtek, de a növekedés megalapozottságának hiányát mutatja, hogy a mủtrágya hatóanyag felhasználás 1991 óta nem éri el 1 ha-ra vetítve az $50 \mathrm{~kg}$-ot. Ennek a hatása egyébként a minóség romlásában meg is mutatkozott. $\mathrm{Az}$ állattenyésztés viszont a baromfihús termelés kis mértékủ növekedését leszámítva rendkivül alacsony szinten stagnál ( $I$. ábra, 3. és 4. táblázat).

\section{1. ÁBRA}

A mezögazdasági termékek bruttó termelése (1986-1990-es évek átlaga $=100)$ (The Production of Agricultural Goods, $100=$ Yearly Avarage Production Between 1986 and 1990)

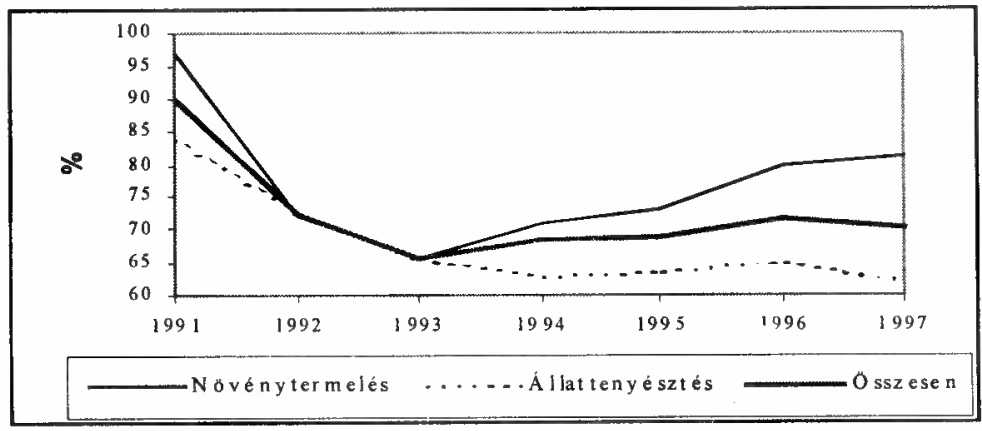

Forrás: Magyar Statisztikai Zsebkönyv. 1997. Budapest, KSH. 1998. 176. o. 
Kelet-Közép-Európa és Magyarország agrárgazdasága az Európai Unióhoz való csatlakozás előtt Tér és Társadalom 12. évf. 1998/4. 21-27. p.

TÉT XII. évf. $1998 \square$

Kelet-Közép-Európa és Magyarország...

\section{TÁBLÁZAT}

Fontosabb növények termésmennyisége és termésátlaga

(The Overall Production of Major Plants and Their Avarage Production per Acre)

\begin{tabular}{|l|r|c|c|c|c|c|c|c|}
\hline \multirow{2}{*}{$\begin{array}{c}\text { Megneve- } \\
\text { zés }\end{array}$} & \multicolumn{4}{|c|}{ Összes hozam (1000 t) } & \multicolumn{3}{c|}{ Átlaghozam kg/ha } \\
\cline { 2 - 10 } & $1986-90$ & $1991-95$ & 1997 & $\begin{array}{c}\text { Ausztria } \\
1996\end{array}$ & $1986-90$ & $1991-95$ & 1997 & $\begin{array}{c}\text { Ausztria } \\
1996\end{array}$ \\
\hline Búza & 6214 & 4380 & 5270 & 1301 & 4880 & 4250 & 4210 & 5010 \\
\hline Kukorica & 6225 & 4981 & 6811 & 1474 & 5630 & 4410 & 6440 & 7670 \\
\hline $\begin{array}{l}\text { Gabona } \\
\text { összesen }\end{array}$ & 14282 & 11455 & 13723 & 4476 & - & - & & - \\
\hline Napraforgó & 745 & 741 & 545 & - & 2030 & 1750 & 1669 & - \\
\hline Cukorrépa & 4513 & 3705 & 3756 & 2890 & 38400 & 31450 & 37970 & - \\
\hline
\end{tabular}

Forrás: Tények és adatok a mezógazdaságról és a falusi életkörülményekröl. Budapest, KSH. 1997. 30. o.; Magyar Statisztikai Zsebkönyv '97 Budapest, KSH. 1998. 177. o.

\section{TÁBLÁZAT}

Állatállomány létszáma és termelése

(The Total Number of Life Animals)

\begin{tabular}{|l|c|r|r|r|c|}
\hline \multicolumn{1}{|c|}{ Megnevezés } & $\begin{array}{c}\text { Mérték- } \\
\text { egység }\end{array}$ & $1986-90$ & $1991-95$ & 1997 & $\begin{array}{c}\text { Ausztria } \\
1997\end{array}$ \\
\hline Szarvasmarha & ezer db & 1650 & 1083 & 871 & 2198 \\
\hline Ebböl: tehén & ezer db & 658 & 468 & $414^{\mathrm{xxx}}$ & $820^{\mathrm{xx}}$ \\
\hline Sertés & ezer db & 8178 & 5149 & 4931 & 3680 \\
\hline Ebböl: anyakoca & ezer db & 658 & 424 & $379^{\mathrm{xxx}}$ & 381 \\
\hline Juh & ezer db & 2165 & 1347 & 858 & 384 \\
\hline Tyúkállomány & ezer db & 55093 & 33582 & 30983 & - \\
\hline Vágóállat összesen: & ezer t & 2273 & 1604 & 1466 & - \\
\hline Tehéntej összesen: & millió l & 2748 & 2094 & 1854 & $3200^{\times \times}$ \\
\hline l tehénre jutó tejtermelés & $\mathrm{l} / \mathrm{db}$ & - & $4935^{\times}$ & 4852 & 4429 \\
\hline
\end{tabular}

${ }^{\mathrm{x}} 1990{ }^{\mathrm{xx}} 1995{ }^{\mathrm{xxx}} 1996$

Forrás: Tények és adatok a mezőgazdaságról és a falusi életkörülményekröl. Budapest, KSH. 1997. 31-32. o.; Ausztria állatállománya. Agrár Európa. 1998. 3., 4.; Mezögazdasági Statisztikai Zsebkönyv. Budapest, KSH. 1997.

A termelés stagnálása, a lehetőségekhez képest rendkívül alacsony színvonala megnehezíti a csatlakozási tárgyalásokat, mert ezt a termelési szintet nem lehet bázisként elfogadni. Ez azt jelentené, hogy a belső fogyasztás növekedése esetén tejet, tojást, húst, gyümölcsöt kellene importálni, miközben a magyar földek bevetetlenül állnának, illetve a falusiak jelentős része munkanélküli lenne. Ezért a tárgyalások során tejból, marhahúsból, cukorból a hazai ellátási szintet kell megcélozni, ez az EU piacait nem zavarná. Az ország adottságai a gabona- és az olajosmag termelésre, valamint szőlö, gyümölcs- és zöldségtermelésre kiválóak. A gabona 50\%-át kitevő kukoricából, napraforgómagból, csonthéjas- és bogyós gyümölcsökből, minőségi borból az EU nem önellátó, így a termés az Unión belül elhelyezhető, a megjelenő többlettermés nem okoz piaci zavart. A búzatermelés pedig olyan minóség előállítására képes, amelyhez hasonló az Európai Unió tagállamaiban nem 
érhetö el. A sertés- és a baromfihús termelés alakulását az ágazat korszerủsítésének üteme határozza meg, hosszú ideig nem remélhető, hogy a termelés a nyolcvanas évek színvonalát eléri.

A magyar mezögazdaság jövöorientált fejlödési pályára állítása egyszerre feltételezi a földtulajdon és a bérleti viszonyok rendezését, a társult gazdálkodás támogatását, valamint a piaci viszonyok rendezését és a tókeellátottság javítását. A történelem kerekét nem lehet visszaforgatni. A jövő egyértelmủen a nagyméretủ, hatékony, integrált termclést folytató gazdaságoké.

Ez nem ideológiai kérdés, ez a versenyképesség kérdése. Mindaddig, amíg a magyar politika ezt nem vállalja fel, versenyképes termelésre képes mezőgazdaság sem alakulhat ki. Ez az a kérdés, amivel az EU-nak is szembe kell néznie. Nem a magyar mezögazdaság jelent az EU parasztságára veszélyt, hanem az újabb WTO megállapodás következtében élesedö verseny, amely az észak- és dél-amerikai, Ausztrál és új-zélandi versenyt fogja növelni.

A magyar mezőgazdaság a termelésének kb. 1/3-át képes exportálni. Ez nem haladja meg az EU jelenlegi importjának 2-3\%-át. Így tehát magyar export dömpingtöl nem kell tartani. Sokkal inkább veszélyes lesz az EU-ra és Magyarországra nézve is, ha nem tudja a mezőgazdasági termelését korszerüsíteni, és hatékonyabbá tenni a tengeren túli versennyel szemben.

Magyarország a fơld kérdését leszámitva nem kíván semmi agrár kedvezményt. Célja, hogy tiszta versenyviszonyok közé kerüljön. A földkérdésben a derogációt is csak az tenné szükségessé, hogy a válság miatt a földek olyan mértékben elértéktelenedtek, hogy a földpiac szabaddá tétele spekulációs célú fơldvásárlásokat eredményezne. Nem fogadható el viszont az, hogy a kompenzációt ne terjesszék ki a magyar mezőgazdaságra, mert az olyan mértékü jövedelemtorzulást okozna, hogy a hegy tetején jövedelmezőbb lenne termelni, mint a termékeny síkságon.

$\mathrm{Az}$ EU érdeke, hogy Magyarországon lezajlódjon egy földkoncentráció, és ezzel csökkenjen az életképtelen kisgazdaságok száma. További érdeke, hogy csökkenjen a mezőgazdasági terület. Ezt egy intenziv erdösítéssel, kb. 700 ezer ha beerdősitésével lehetne elérni. További önérdekủ támogatást jelentene a területek egy részén az extenzívebb állattartás fejlesztése ( $p l$ juh, kecske, húsló, szarvasmarha stb.), többcélú víztározók létesítésének a támogatása. Elsösorban ezek azok a területek, amelyeket célszerủ lenne az Európai Uniónak még a csatlakozás elött határozottan támogatni, mert úgy biztosítana munkahelyeket és helyi jövedelmet, hogy az a versenyző termékek területén nem jelentene piaci többletkínálatot. Itt természetesen ismét elötérbe kerülhet az az ellenérv, hogy a kelet-közép-európai országok, így Magyarország csatlakozása mennyi fejlesztési forrást köt le. Erre csak azt felelhetjük, hogy a történelemben nincs sok példa arra, hogy egy gazdaságilag fejletlenebb és fejlettebb régió kapcsolatából ne a fejlettebb húzna nagyobb hasznot. Az átmeneti zavarok is nagymértékben mérsékelhetők, ha az egyes országokkal kapcsolatos kérdéseket külön-külön, és nem együttesen vizsgálják és próbálják meg a feszültségpontokat kezelni. 


\section{Jegyzet}

${ }^{1}$ A tanulmány az OTKA T1620I nyilvántartási számú pályázat támogatásával készült.

\section{Irodalom}

A magyar mezógazdaság és élelmiszeripar számokban. (1997) Budapest, Földmủvelésügyi Minisztérium.

Ausztria állatállománya (1998) - AgrárEurópa. 3., 4.

Benet I. (1997) Rendszerváltás és agrárgazdaság. A magyar agrárgazdaság jelene és kilátásai. Budapest, Magyar Tudományos Akadémia.

Inotai A. (1998) Magyarország, az Európai Unió és a 10 társult ország közötti külkereskedelem jellemzỏi és új irányzatai. 1989-1997. Budapest, OMFB, MTA Világgazdasági Kutató Intézete.

Magyar Statisztikai Zsebkönyv '97. (1998) Budapest, KSH.

Mezögazdasági Statisztikai Zsebkönyv (1997) Budapest, KSH.

Tények és adatok a mezõgazdaságról és a falusi életkörülményekröl. (1997) Budapest, KSH.

Varga Gy. (1998) Tárgyalások, súlypontok. - Magyar Mezógazdaság. 29.

\section{THE AGRICULTURE OF CENTRAL EUROPE AND HUNGARY BEFORE THE ACCESSION TO THE EUROPEAN UNION}

\section{ATTILA BUDAY-SÁNTHA}

As the date of the EU accession approaches, one can more and more often hear opinions within the EU - and especially in Austria - that the date of the accession should be postponed to a later date, and that agricultural assistance (compensations) should be unequally distributed - to the detriment of the newly joining countries. The essay draws the attention to the fact that the accession countries do not make a homogeneous agrarian region, they are countries with different endowments. The emerging problems should be examined and tackled separately in the individual countries. The development of the economy and the raise in the living standards would not only slow down the movement of labour (which is considered as a danger), but the increase of domestic consumption would also prevent the production of food surplus. 